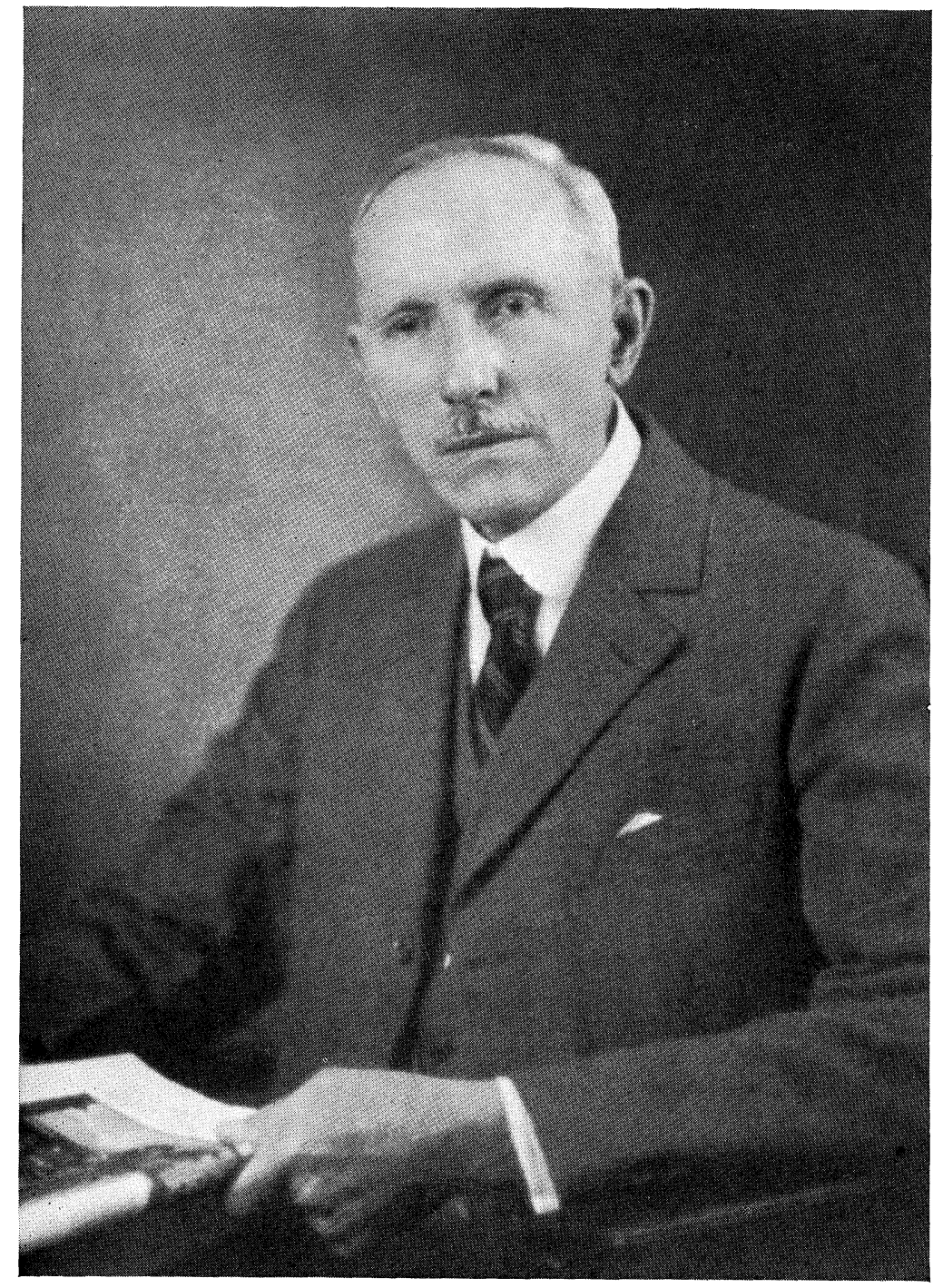

THlnrtàn

THehrutury 2 a, 1959-Aumut 14, 1930 



\section{FLORIAN CAJORI}

On August 14, 1930, at his home in Berkeley, California, Professor Florian Cajori, one of the most prolific writers on the history of mathematics, physics, and astronomy in this generation, died in the seventy-second year of his age. For some time his health had been failing, and being further weakened by a hospital operation his system was unable to withstand the attack of pneumonia which proved fatal.

He was born at St. Aignan, near Thusis (Canton of Grisons), Switzerland, on February 28, 1859, and came to the United States in 1875, at the age of sixteen. His early education was received at Zillis (Thusis) and Chur, Switzerland. Soon after coming to America he entered the State Normal School at Whitewater, Wis., where he remained for two years (1876-1878). A little later he entered the University of Wisconsin, graduating with the degree of B.S. in 1883, and receiving the degree of M.S. in 1886. After taking the bachelor's degree he spent a year and a half at Johns Hopkins University (Jan., 1884June, 1885). He was then elected assistant professor of mathematics (1885) at Tulane University, becoming professor of applied mathematics two years later (1887). In 1889 he went to Colorado College as professor of physics, which position he held for nine years. From 1898 to 1918 he was professor of mathematics in the same institution, serving also as dean of the department of engineering from 1903 to 1918 . In 1918 he was called to the University of California to accept the position of professor of the history of mathematics, doubtless the first man ever to receive this title, and one of the few to have a university position allowing the entire time of its occupant to be given to research, writing, and teaching in this particular field. The appointment, which dated from July 1, 1918, was an exceptional honor and the result amply justified the university in affording the unique opportunity. On July 1, 1929, he retired from active teaching, with the title of professor emeritus.

Professor Cajori's literary activity in his chosen field was far more extended than is generally recognized. The list of his articles in scientific journals is extensive, and the subjects treated give evidence of his wide range of interests in the field of the history of science.

Among the publications to which he was a contributor may be mentioned the following: American Journal of Mathematics, American Mathematical Monthly, Annals of Mathematics, Archeion, Archivio di Storia della Scienza, Bibliotheca Mathematica, Bulletin of the American Mathematical Society, L'Enseignement Mathématique, Isis, Silliman's Journal, Loria's Bollettino, Mathematical Gazette (England), Nature (London), Mathematics Teacher, Popular Astronomy, Popular Science Monthly, Revista Matematica HispanoAmericana, School and Society, School Science and Mathematics, Science, Scientia, Scientific Monthly, Schlömilch's Zeitschrift, and the serial publications of both the University of California and Colorado College. To these periodicals he contributed no less than 140 articles (including reviews) during the period of his residence at the University of California,-an average of nearly one each month. The total number of items in his bibliography during 
his forty years of active writing was, however, much greater, being bitween three and four hundred. It is expected that this feature of his work will be treated in extenso by Professor Archibald in an article to appear in Isis. Mention should also be made of his textbooks.

He will, however, be best known by his numerous historical works, the publication of which extended over a period of forty years. The first of these works was The Teaching and History of Mathematics in the United States (Washington, 1890). Although quite naturally lacking in the scholarship and thoroughness displayed in the publications of the last years of his life, it laid out a line of study which was quite new in this country and which served a worthy purpose in creating an interest in the subject.

His next three works were in the nature of general histories in his fields of major interest. The History of Mathematics appeared in 1894, the History of Elementary Mathematics in 1896, and the History of Physics in 1899. Each was written under conditions that were evidently not favorable to exhaustive research in the original sources from which history should draw; indeed, even the secondary sources of information were too limited to admit of the work of which he afterward showed himself capable. His first opportunity to display his real ability came when Moritz Cantor invited him to contribute a section on arithmetic to volume IV of the Vorlesungen über Geschichte der Mathematik (Leipzig, 1908). This was a distinct honor, and the rule of noblesse oblige showed itself. He went to the sources and was thus enabled to write as one having authority.

Thus there upened a new era in his work,- - the era in which he found himself. In the next year there appeared his History of the Logarithmic Slide Rule (1909), involving a line of investigation apparently suggested to him partly by his duties as dean of the department of engineering, and partly by his studies in connection with the Cantor project. He was no longer content with depending upon the works of others; others could now depend upon him. It would seem that it was the study of the slide rule that led him to write his first biographical work, the William Oughtred (1916), in which he gave a worthy résumé of the life of "a great seventeenth-century teacher of mathematics" (using the word "teacher" in a broad sense) and, indeed, of one who may perhaps justly be called the greatest in England. At about this time (1917 and 1919) he gave a much-needed revision to his two histories of mathematics, improving both their style and content. The History of Elementary Mathematics was translated into Japanese in 1928, and the History of Physics was revised in 1929. His other venture in the field of biography was made much later, after he had gone to Berkeley,-The Chequered Career of Ferdinand Rudolph Hassler, first Superintendent of the United States Coast Survey (1929). In this he gave evidence of extensive search after material and of having found it and skillfully used it to make this description of the life and works of his compatriot a worthy contribution to the history of science in their adopted country.

Three special studies in the history of mathematics stand out, however, above all the rest, and by these he will longest be remembered. They illustrate the words of the greatest of the poets laureate of England,

"That men may rise on stepping stones

Of their dead selves to higher things;" 
for, after all, Professor Cajori's earlier works were as mere stepping stones to those of his last few years at Berkeley. The first was his History of the Concepts of Limits and Fluxions in Great Britain from Newton to Woodhouse (1919), which may be looked upon as a kind of inaugural address at the University of California. It gave evidence of a more careful examination of sources than any of his previous works, even the ones on the slide rule and on Oughtred. It was in the preparation of this work, no doubt, that he found a stimulus for his essay on Nezuton's Fluxions and the one on the Law of Gravitation, each of which he prepared for the Bicentenary meeting in honor of Newton, held at New York in 1927, and perhaps for the edition of the Principia and Optics upon which he had nearly completed the work at the time of his death, and which will, it is understood, be published.

The second of his special studies was The Early Mathematical Sciences in North and South America (1928), a series of essays rather than a connected discourse, but none the less a genuine contribution to the history of science in the New World. It is no disparagement of the work to say that its value lies no less in the extensive bibliographies at the close of the several chapters than in the text itself, for not only do these show a wide range of reading on the part of the author but they will prove of great value to future students in this field. Naturally the work deals with astronomy, geodesy, and physics rather more than with pure mathematics, - the result of the early influence of England and Spain at a time when these three subjects were uppermost in the applications of the science. In the same year (1928) he published his Mathematics in a Liberal Education, an appeal for a better knowledge of the purpose of mathematical training.

The third of the special studies will, however, stand out as the real monument to Professor Cajori's life work, The History of Mathematical Notations ( 2 vols., 1928, 1929). It is in this that he appears at his best, and long after our current histories of mathematics are forgotten, this will remain as one of the most important contributions of our time to any of the special phases of the general subject. That he lived to see the conclusion of this work, and to see the worthy form in which it came from the press, and also to see the practical conclusion of his manuscripts on the Principia and the Optics, must have been a source of special gratification to him as it is to scholars generally throughout the world of science.

Of the honors conferred upon him it is not necessary to speak at any length. Gratifying as they were, they weigh but little in comparison with his accomplishments. He held the degrees of Ph.D. (Tulane, 1894), LL.D. (University of California, 1912, and Colorado College, 1913), and Sc.D. (Wisconsin, 1913). He was a member of the American Mathematical Society, the Mathematical Association of America (president, 1917), the Deutsche Mathematiker-Vereinigung, the American Association for the Advancement of Science (vice president of Section L, 1923), the Mathematical Association (England), The National Council of Teachers of Mathematics, the History of Science Society (council member), and the Circolo Matematico di Palermo, and was a fellow of the American Academy of Arts and Sciences.

On September 3, 1890, at St. Louis, Mo., he was married to Elizabeth G. 
Edwards, who survived him, as did their only son, Lieut. Florian Anton Cajori, who served in France during the World War.

It is impossible to summarize in a few words the esteem in which Professor Cajori was held by those who knew him either personally or through his writings. His gentle manner and unfailing kindness endeared him to all with whom he was associated, and at the same time there was a bond between him and many thousands whom he led to appreciate more fully that range of knowledge which makes up what a Hindu master so appropriately called "the science venerable."

David Eugene Smith 